\author{
Николай Антропов \\ Институт языкознания имени Якуба Коласа НАН Беларуси \\ Минск \\ ORCID: 0000-0001-6966-572X; e-mail: antropov50@gmail.com
}

\title{
Дифтонгические сочетания модели *telt: вновь о восточнославянских отражениях
}

Реферат: Наименее последовательными среди интерконсонантных праславянских дифтонгических сочетаний плавных с $о$ и е были восточнославянские реализации *telt. Наряду с ожидаемым в соответствии с аналогичным «развертыванием» полногласия в *tert > teret, т. е. развитием полногласных сочетаний telet c $l(=l)$, реально существующих, но на общем фоне единичных, возникают регулярные континуанты *telt $>$ tolot (со своеобразной промежуточной стадией *telt $>$ telot, обусловленной качеством начального согласного), в которых плавный в результате регресс и в ной ассимиляции к последующему твёрдому согласному изменился в $t$. Однако в отдельных случаях направление влияния в сочетании *telt было, судя по всему, п р огр е с с и в ы м : мягкий начальный консонант способствовал сохранению $е$ с последующим влиянием на качество $l$, в результате чего возникающий после $l$ глайд также был переднерядным, нелабиальным и прояснялся в гласный полного образования такого же качества. В статье на достаточно репрезентативном материале доказывается, что развитие полногласия в восточнославянских языках по модели *telt > telet / telot является столь же закономерным, как и постулируемый до сих пор в литературе, особенно учебной, переход *telt > tolot.

Ключевые слова: восточнославянское полногласие, регрессивная/прогрессивная ассимиляция, этимология, диалектография.

\begin{abstract}
Diphthongal combinations of the *telt model: more reflections on the East Slavic languages. Among all inter-consonant Proto-Slavic diphthongal combinations of liquid consonants with $o$ and $e$, the East Slavic *telt was the least consistent. In accordance with a similar "deployment" of pleophony in *tert> teret, there was an expectation of the development of full-voiced combinations telet with $l(=l)$, which indeed exist as isolated cases in the general background. Regular continuants *telt $>$ tolot appear (with a rather particular intermediate stage *telt $>$ telot, caused by the quality of the initial consonant) where a liquid consonant has changed into $t$ as a result of regres s i ve assimilation to the subsequent hard consonant. However, it appears that in some cases, the influence in the *telt combination was progressive : a soft initial consonant contributed to the preservation of $e$ with a subsequent influence on the quality of $l$, resulting in a glide that appeared after $l$ being front, unrounded and clearing up into a vowel of complete formation of the same quality. Based on representative material, the article proves that, according to the *telt $>$ telet / telot model, the development of pleophony in East Slavic languages is as natural as the *telt $>$ tolot transition that has been postulated so far in literature, especially academic literature.
\end{abstract}

Keywords: East Slavic pleophony, regressive/progressive assimilation, etymology, dialectography. 
Полногласие составляет собою не господство гласных над согласными, но их равновесие...

В.А. Максимович

Вынесенная в качестве эпиграфа фраза принадлежит одному из первых ${ }^{1}$ исследователей восточнославянского полногласия и, в сущности, удивительным образом объединяет практически все известные теории его образования, которые были выдвинуты за более чем 180 лет, минувших от времени первой публикации работы выдающегося украинского учёного-энциклопедиста в 1839 г. Не будет преувеличением отметить, что именно слоговое «равновесие» в духе по существу пред-младограмматических представлений В.А. Максимовича явилось результатом развития в (пра)восточнославянских диалектах дифтонгических сочетаний

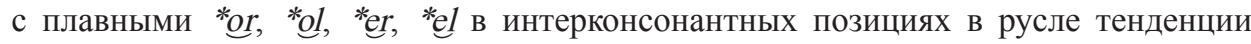
праславянского языка к открытому слогу.

Как известно, процесс преобразования первых трёх проходил по общей модели, когда появлявшийся в полногласном сочетании второй гласный звук был по качеству идентичен первому, т. е. *tort $>$ torot, $*^{*}$ tolt $>$ tolot, * ${ }^{*}$ tert $>$ teret $^{2}$. Иная картина наблюдается в развитии сочетания *telt, где ожидаемое и в определенном смысле естественное telet появляется далеко не всегда, а фактически факультативно и как будто бы только тогда, когда первый и последний консонанты слоговой группы *telt были мягкими (или смягчались перед гласными переднего ряда), cp., например, ${ }^{*} s^{(\prime)}$ elz(') ena $\rightarrow{ }^{*}$ selezena $\left(>*^{*}\right.$ selezen $\left.k a\right)$. В большинстве других лексических позиций *telt развивалось аналогично модели *tolt, т. е. в группу tolot, кроме случаев, когда первый консонант был заднеязычным и в результате первой палатализации преобразовывался в мягкие шипящие $\check{z},, ~ \check{s} ’$ и аффрикату $\check{c}$, после которых переход е > о был невозможен ${ }^{3}$. Таким образом, обобщённо схему развития *telt можно представить как *telt > telet / telot / tolot.

Понятно, что феномен «неправильного», как бы незакономерного или, во всяком случае, необычного 4 развития *telt в восточнославянских языках был замечен уже первыми исследователями полногласия. Так, на разнобой в реализациях «перемены в русском полногласии еле на оло» обратил внимание уже П.А. Лавровский в постановочной для середины XIX века статье «О русском полногласии», однако связал это изменение с последовательным развитием «в этих случаях Ђ в а», обобщив далее: «Как ни мала масса слов полногласных с льь, но из неё можно смело делать заключение, что [...] еще в доисторическую пору бо́льшая

1 Он также и автор термина «полногласие» (Скляренко 2007, 516); см. параграф «О полногласии русского языка» в (Максимович 1839), а также несколько более подробно в разделе «Исследование о полногласии» в (Максимович 1848).

2 Последующие изменения вокальных элементов этих сочетаний, а именно сужение гласных, аканье / яканье, нулевая редукция и др., обусловлены позднейшими фонетическими процессами в отдельных восточнославянских диалектах и их группах.

3 Разумеется, впоследствии после отвердения аффрикаты и шипящих изменение $e>o$ стало возможным также в первом слоге полногласного сочетания, ср., например, с одной стороны, др.-рус. желобъ (XV XII вв.), а с другой - ст.-укр. и ст.-бел. жолобъ (кон. XV и нач. XVI вв.).

${ }^{4}$ В.И. Шерцль, например, с чувством отмечает, что «лr, рг переходят въ еле, ере, ль даже в оло» (Шерцль 1871, 348). 
часть корней этих слов в русском языке изменила ль въ ла и уже отсюда образовала полногласное оло» (Лавровский 1858, 208).

А.А. Потебня в монографии «К истории звуков русского языка» проблему полногласия выделил в отдельную большую главу, именно «VII. Первое полногласие (оро = ра и пр.)», где необходимо отметить любопытный пассаж: «Если спросим себя, как еле напр.[имер] в предполагаемом мелеко могло перейти въ молоко, то удовлетворительную аналогию для этого перехода будет очень трудно найти» (Потебня 1876, 160).

Ещё более определенно на эту тему позже высказывался А.А. Шахматов, посвятивший подробному лингвистическому анализу одной из наиболее существенных общих черт восточнославянских языков богатую новыми идеями, насыщенную историческим и диалектным материалом большую статью в двух частях с названием, аналогичным потебнянскому, опубликованную в 1902 г., а в виде монографии годом позже - «К истории звуков русского языка. О полногласии и некоторых других явлениях» (Шахматов 1903). Именно здесь (в значительной степени под влиянием идей, ранее высказанных Ф.Ф. Фортунатовым) была выдвинута идея особого качества гласного е перед плавным $t$, т. е. et, который «в общеславянскую эпоху» перешёл в ӧ закрытое с образованием дифтонгиче-

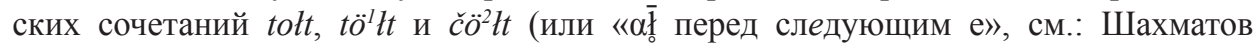
$\left.1903,96^{5}\right)$, чьё развитие и привело к различным результатам восточнославянского полногласия в слоговой группе telt предшествующего периода (Шахматов 1902, 307, 360-361). Как раз эта гипотеза явилась обоснованием однозначного и более позднего утверждения, о котором упомянуто выше: «Ошибочно думать, чтобы общеславянскому el могло соответствовать в русском языке el'e» (Шахматов $1915,153)$.

Всё сказанное, конечно, достаточно хорошо известно, однако, во-первых, не является излишним напомнить об идеях предшественников, а во-вторых, в последние годы обнаружился новый исследовательский интерес к незакономерным - конечно, только на первый взгляд - восточнославянским отражениям *telt, причем для обеих статей, в которых обсуждается эта проблема, импульсом послужили новые возможности для анализа рассмотренных ранее А.А. Шахматовым лексических (этимологических) гнёзд: *telp (// *tblp / *tъlp) и *selp (Илиади 2014; Куркина 2018). Нельзя не согласиться с А.И. Илиади, который отмечает, что среди слов, историю которых исследует А.А. Шахматов, «есть ряд таких, которые и сейчас, спустя сто с лишним лет, еще нуждаются в этимологическом освещении» (Илиади 2014, 111). При этом автор, подробно освещая этимологию и семантику этимологических гнёзд *telp, *selp и генетически (или семантически) связанных с ними корневых континуантов, обращает далее внимание ещё на 5 лексем, относящихся «к той немногочисленной группе слов, которые демонстрируют вост.-слав. отражение группофонемы telt не в виде ожидаемого 'классического' tolot, как в молоко < *melko, а в виде telet», а именно: *belbenь (> укр. диал. бе́лебень 'возвышенное и открытое место'), *čelnъ, *čelnъkъ (> рус. диал.

\footnotetext{
${ }^{5}$ На «čisto umelou konštrukciou» фортунатовско-шахматовских построений внимание уже было обращено (см. Peciar 1952, 65).
} 
челено́ 'звено брёвен в плоту', че́лень 'количество паёв в поле', укр. диал. челенок 'в пальце: кость, сустав'), *želsti (> рус. желести 'платить, искупать вину'), *želd- (> pус. ожеледица, укр. о́желе́дь, ожеле́да 'гололедица'), наконец, *telmenь при укр. телемень - название притоков нескольких рек 6 .

Между тем, как бы ни была немногочисленна группа слов, о которой пишет кировоградский лингвист, она, как показывает материал (обще/пра)славянских словарей (ЭССЯ; SP; Derksen 2008) и этимологических словарей отдельных славянских языков, может быть дополнена.

1. Номинации с однородным развитием *telt: рефлекс -еле-.

1.1. *belna / *belnb 'белена; паслён', хотя ряд этимологических словарей предполагает уже *belena, например, (ЭССЯ I, 185), с чем можно согласиться, но только при условии, что имеется в виду позднепраславянский период с уже отчетливой диалектной дифференциацией праславянского. Вероятно, именно так следует понимать *belena в (БЕР I, 59), где для подтверждения праславянской реконструкции приводятся восточнославянские лексемы рус. белена́ и укр. беле́на. Однако ЭССЯ в соответствующей статье даёт параллельные реконструкции *belnъ / *belena ${ }^{8}$, которые «отражают древнее наличие двух праслав. вариантов данного слова», что иллюстрируется, кроме др.-рус., рус. и рус. диал., также сербохорв. (черногор.) белѐна (единичная фиксация с пометой «покр.[ајинска реч]» в PCA I, 439), слвц. belian и некоторыми «примыкающими» номинациями.

Не вдаваясь в дискуссию относительно корректности привлечения этих лексем, а именно их диалектного статуса и словообразовательной структуры, которая может отражать «народную» этимологию (а именно связь с *běl-), см., в частности, (SP I, 202 ${ }^{9}$ ), заметим, что реконструкции *belna в ЕСУМ и её коррелята *belnь в ЭССЯ с полногласным развитием -еле- в восточнославянских языках ${ }^{10}$, конечно, столь же естественны, как и иные, упомянутые выше (см. также: Шевельов 2002, 127 (реконструирет прасл. *baln-); Аникин 2007-, III, 67-68).

1.2. *melnъ / *melnь / *melna: ст.-рус. меленъ, рус. (арх., волог., новг., пск., смол.) ме́лен, ме́лена, мелён, ме́лин, ме́лень 'рукоятка (ручка) жернова и под.; жернов; мельница' (ЭССЯ XVIII, 89; СРНГ XVIII, 97; НОC, 550; СРГРС VII, 274; ПОС XVIII, 127), сюда же волог. ме́ленка 'деревянный запор в виде вертушки' (СВГ IV, 80), укр. милін, (центр./вост.-) полес. (= бел. и укр. диал.) мелён, милён, мельйо́н 'рукоятка (ручка, палка) у ручной мельницы, жернова' (Никончук 1979,

${ }^{6}$ В качестве иллюстраций приводятся только отдельные восточнославянские продолжения реконструированных праславянских форм с минимальной семантической характеристикой; полностью см. (Илиади 2014, 116-117).

7 Приводятся только основные значения.

${ }^{8}$ Ниже (I, 187) также *belnь с продолжением в ст.-польск. bleń 'белена', к которому можно добавить соответствующую полногласную форму с мягкой финалью - черниг. бе́лень 'тж’ (ЕСУМ I, $165)$.

9 Здесь автором статьи Ф. Славским реконструированы *belnъ и *blnъ.

10 Р. Дерксен, приводя в сильно редуцированном виде реконструкции и материал из ЭССЯ, в примечании к двум восточнославянским, но здесь исключительно русским номинациям с -еле-, вряд ли последовательно (но зато фактически повторяя суждение А.А. Шахматова столетней давности) замечает: «Ru. belen- cannot reflect *beln-, which would regularly yield *bolon-» (Derksen 2008, 36). 
306), сюда же производные с суф. -óx, -óp, -ópa, -ýн, -ýp, -ýx (Никончук 1979, 306), бел. диал. (берез., в.-двин., дауг., лудз., рос., сен., толоч.) ме́лін, мёлін, мялён 'рукоятка (ручка, палка) у ручной мельницы, жернова' (ЭСБМ VII, 11, 140; Сл. ПЗБ ІІІ, 103-104).

Как и в предыдущем случае, ЭССЯ предлагает коррелятивную неполногласно-полногласную пару *melnъ / *melenъ, что, в принципе, неудивительно, так как обе статьи написаны О.Н. Трубачёвым. Однако необходимо отметить, что в случаe *melenъ иные славянские полногласные лексемы (генезис и статус которых может обсуждаться), кроме естественных восточнославянских, здесь отсутствуют.

ЭСБМ, ссылаясь на литературу по славяно(белорусско)-балтийским языковым связям (Э. Блесэ, А.А. Вержбовский, Ю.А. Лаучюте) видит в белорусских диалектных формах ме́лін, мёлін балтизмы (с сответствующей территориальной привязкой к белорусско-литовскому/латвийскому пограничью, хотя эти лексемы и их варианты, как показывает привлечение иных источников, распространены всё-таки шире, а именно с диффузией в центральнобелорусские и полесские говоры), имея в виду фонетически близкие лит. milinỹs и лат. millens ${ }^{11}$ с аналогичной семантикой ручки / рукоятки жернова или ручной мельницы и под. Однако А.Е. Аникин совершенно справедливо отметил, что связь славянских лексем, восходящих, согласно ЭССЯ, к праславянской дублетной паре, с балтийскими фактами «может пониматься только как генетическая» (Аникин 2005, 220).

1.3. *želza 'железа́ (в разных значениях)': рус. железа́, яросл. желе́зо 'опухоль на теле’ при бел. зало́за, укр. за́ло́за (СРНГ IX, 103, 107; ЭСБМ III, 292; ЕСУМ II, 229; Derksen, 557).

2. Номинации с неоднородным развитием *telt: рефлексы -еле- / -оло-.

2.1. *melnbje 'смалывание на мельнице; помол; размол':

а) редкие ст.-рус. меление, рус. меле́нье, ст.-бел. меленье, ст.-укр. меленє (ЭССЯ XVIII, 89-90; ГСБМ XVII, 316; СУМ XVI-XVII, 17, 101), сюда же дериват - рус. вят. мелёнка 'хлебная мера на 1,5 пуда ржи' (СРНГ XVIII, 97 по источнику 1887 г.);

б) вероятно, единичное ${ }^{12}$, но всё-таки при двух фиксациях, рус. диал. (терск., ворон.) моло́нье (СРНГ XVIII, 237). В ЭССЯ предполагается возможность реконструкции этих гапаксов «в некоторых случаях - в обновленной форме *mel-enъ», что не представляется обязательным.

2.2. *melvo:

a) ст.-рус. мелево, меливо 'помол, процесс помола; зерно для помола' (СлРЯ XI-XVII, 9, 78), рус. волог. ме́лево 'рукоятка жернова ручной мельницы' (CВГ IV, 80; СРГК III, 218), ‘что мелется, будет молоться или смолото; мука' (Даль $1903-$ 1909, II, 915), мелевó 'всё, что привезено на мельницу для обмолота' (Бурнашев 1843-1844, I, 392), арх. 'помол' (СРНГ XVIII, 95), пск. 'что необходимо молоть'

11 Наличие этого слова не подтвержается основными словарями латышского языка, о чём свидетельствует А.Е. Аникин, который предлагает учитывать в этом аспекте родственные или близкие по форме и семантике иные латышские лексемы (Аникин 2005, 220).

12 Во всяком случае, отсутствет в базе Русского диалектного гизауруса (РДГ). 
(ПОС XVIII, 127), укр. ме́ливо 'помол, зерно на помол; мука' (ЕСУМ III, 505), бел. ме́ліва, ме́ліво 'размол; зерно на размол; что будет молоться’ (ЭСБМ VII, 11);

б) по всей вероятности, единичное (также отсутствует в РДГ) рус. пск. мо́лово 'то, что молотят; то, что получается при молотьбе' (СРНГ XVIII, 220; ПОС XVIII, 311 с пометой пуст. ${ }^{13}$; ЭССЯ XVIII, 93; все из одного источника Картотеки ПОС). Хотя совершенно исключить предполагаемое ЭССЯ продолжение праславянской номинации с корнем *melv- нельзя, статус очевидного уникализма всё-таки может свидетельствовать в пользу вторичного образования - от глагола молотить.

М. Фасмер предлагает для русской номинации с -еле- «праслав. ${ }^{*}$ melivo $^{14}$, потому что *melvo [...] дало бы в вост.-слав. *молово» (Фасмер 1964-1973, II, 595); к этой этимологии присоединяется также ЭСБМ, а ЕСУМ, не реконструируя специально праславянский этимон, включает украинское ме́ливо в этимологическое гнездо молоти.

3. Номинации с неоднородным развитием *telt: рефлексы -еле- / -ело- / -оло-.

3.1. *pelva 'мякина, полова; отходы при провеивании зерна, молотьбе ${ }^{15}$ ':

а) ст.-рус. пелева (СлРЯ XI-XVII 14, 187), рус. диал. пе́лева, пеле́ва, пелева́, пе́лево (СРНГ XXV, 321; СВГ VII, 23); подмоск. пиле́ва (ОЛА 2019, 154: p’i'l'evə); не фиксируемое словарями укр. *пелева, которое ЕСУМ (IV, 331) восстанавливает по производным пеле́вня, пеле́ве́нь, пеле́вни́к 'стайня, хлів; стодола';

$\mathrm{a}^{1}$ ) рус. диал. пелёва, пе́лёва, пелёва́, пилёва (СРНГ ХХV, 321-322; НОС, 797; ОЛА 2019, 154: 'p'el'ova, p'elo'va, p'il'ova);

б) рус. диал. (арх., волог.) пело́ва (ОЛА 2019, 154: p’e'łova ${ }^{16}$ ), сюда же семантически связанные производные из источников, в которых не отмечены исходные формы: новг. пело́вый '(хлеб) мякинный, приготовленный из мякины’ (Даль 19031909, III, 68 ${ }^{17}$; HOC, 798);

в) ст.-рус. полова (СлРЯ XI-XVII 16, 230-231), рус. поло́ва, диал. поло́ва, по́лова, полова́ (СРНГ 29, 86), укр. поло́ва, ст.-бел. полова (ГСБМ XXVI, 169), бел. пало́ва ${ }^{18}$.

13 Т. е. Пустошкинский район, находящийся на юге Псковской области.

14 С очень сомнительным суффиксом для праславянского слова.

15 Приводятся только основные значения.

16 Фиксируется в следующих 6 пунктах сетки ОЛА: 543 (Вальтево. РФ, Архангельская обл., Пинежский р-н), 569 (Гавриловское. РФ, Архангельская обл., Каргопольский р-н), 587 (Плоское. РФ, Вологодская обл., Бабаевский р-н), 588 (Старина. РФ, Вологодская обл., Бабаевский р-н), 589 (Семеновская. РФ, Вологодская обл., Вытегорский р-н), 602 (Верхне-Ерогодский Починок. РФ, Вологодская обл., Великоустюгский р-н).

17 Здесь же производное пело́вня 'мякинница, или сарай для мелкого скотского корма'.

18 Следует иметь в виду, что лексему в указанном значении необходимо отделять от весьма частотного омонима пало́ва с семантикой 'половина, 1/22. Наиболее полно номинация с исследуемыми значениями представлена в картографической экстраполяции диалектных форм в лексическом атласе белорусских народных говоров, см. (ЛАБНГ ІІ, к. 238 «Мякіна», к. 243 «Адходы пры паланні»). 
Первые три позиции с -еле- / -ело- представлены многочисленными фиксациями в ряде русских говоров, однако с выраженной концентрацией в сев.-рус. ${ }^{19}$, что особенно наглядно видно на карте № 62 *pelva в (ОЛА 2019); лексемы с -олораспространены повсеместно.

Этимологические словари для восточнославянских номинаций с -оло- предлагают прасл. *pelva (Фасмер 1964-1973, III, 312; ЭСБМ VIII, 132; ЕСУМ IV, 496; ESJSt XI, 658; Derksen, 395). Для лексем с -еле- и его варианта -ел'о- (-елё-) уже M. Фасмером реконструируется полногласный вариант для *pelva, т. е. *peleva; то же см. в ЭСБМ и ЕСУМ (IV, 331). Однако, как и в рассмотренном выше случае с парой *melnъ / *melenъ, в других группах славянских языков номинации с полногласными сочетаниями отсутствуют.

Иной взгляд на развитие полногласия с -еле- был предложен А.А. Шахматовым, который считал, что «пелевня [...] заменило форму половня под под влиянием пелы, пельве в значении мякина» с опорой на запись в 1-й Новгородской летописи под 6636 (1128) годом: пелъми тв. мн. (Шахматов 1915, 153)20. Между тем, и сама идея, и привлечённая древнерусская номинация вызывают вопросы. Оригинальный текст, на который ссылается А.А. Шахматов, следующий:

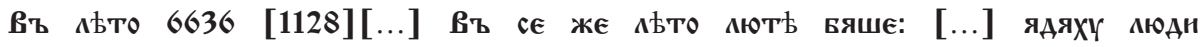

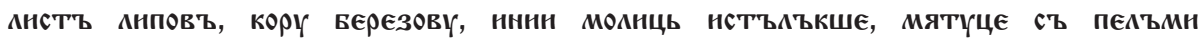
и съ соломюю (НПЛ 1950, 22 21 ).
}

Этой же записью иллюстрирует лексему пельл с пометой «множ.»[ественное число] И.И. Срезневский (1893-1912, II, 894), приводя здесь же современные ему рус. диал. формы пель, пелева 'мякина', пелева 'овсяные отруби' и укр. полова.

Таким образом, по Шахматову, пель, пельве (здесь Gsg) относится к типу склонения на *-z, однако зафиксированная в НПЛ форма Ipl пельми этому противоречит, так как для этого типа склонения правильная падежная форма - пелъвами (как букъвами и под.). Помета «множ.» при пель у Срезневского, скорее всего, означает Plt c семантикой собирательности и логично вводит номинацию либо в тип склонения на *a с незафиксированным, но совершенно реальным др./ст.pyc. пела ${ }^{22}$ (здесь, однако, обычная форма Ipl пелами, а пелъми может быть только

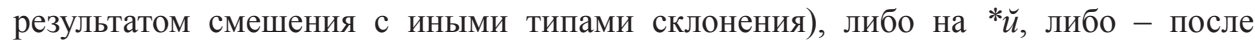

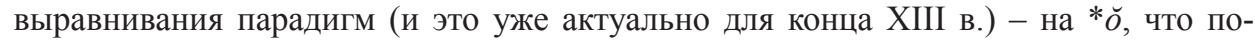

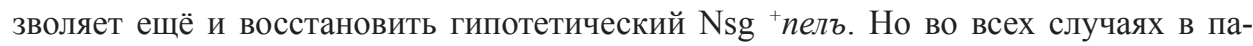
радигме будут отсутствовать формы с -в-, без которых идея контаминации (см.

\footnotetext{
19 В.И. Даль, однако, пеле́ва даёт с пометой «запд.» - западное.

20 Здесь к месту отметить, что наименование рус. пела ед. (наряду с пелева, полёва и др.) ввёл в словарную статью полова своего этимологического словаря уже Н.В. Горяев (1896, 271), а А.Г. Преображенский (1910-1914, II, 33) в статью пела́ - лексемы с -еле-, -елё-, -ело-.

21 По мнению исследователя НПЛ Б.М. Клосса, эта часть летописи, до 1234 г., «писана двумя почерками конца XIII в.» (Клосс 1987, 246).

22 Ср. рус. диал. пела́ с распространением, согласно (СРНГ 25, 321), по преимуществу в севернорусских говорах.
} 
выше у Шахматова: «под влиянием пель,, пелъве»), по меньшей мере, малопродуктивна.

Ещё одну версию, но на иных теоретических основаниях, выдвинул В. Махек: «bylo tedy *pel-eu-, což slovanština převedla k a-kmenům (podle *solma, sláma, obé jsou pozůstatky po mlácení!; s týmž slovem má i stejnou intonaci, r. polóva jako solóma, takže ražený přizvuk nemusí být u pelva původní a nemusí tedy ukazovati na dlouhé ě)» (Machek 1957, 375).

Однако и это соображение не может быть принято без оговорок, так как базируется не на внутреннем фонетическом развитии праславянского дифтонгического сочетания в ряде славянских диалектов (что априори должно предполагаться при праславянских реконструкциях), а на аналогии ${ }^{23}$ только части русс к и х диалектных форм с сочетаниями иного типа.

Таким образом, очевидно, что как прасл. *pely и *pelva, так и их восточнославянские продолжения являются параллельными однокорневыми образованиями ${ }^{24}$ с естественной для диалектов праславянского развитием организующего семантического центра: 'солома' $\rightarrow$ 'отходы при молочении' // 'мякина'. Что же касается собственно фонетического аспекта, то представленный выше материал восточнославянских языков и их диалектов позволяет утверждать, что развитие *pelva $\rightarrow$ peleva (с позднейшим pelova при переходе $e>o$ в соответствующей позиции) является таким же естественным и регулярным, как и *pelva $\rightarrow$ polova. Заметно менее частотной является модель восточнославянского полногласия типа *pelva $\rightarrow$ pelova, в которой теоретически можно было бы предположить отвердение плавного в форме pel'ova ${ }^{25}$, если бы этому не противоречила ареальная характеристика зафиксированных номинаций исключительно в севернорусских (архангельских и вологодских; сюда же новг. пело́вый) говорах, в которых группофонема «гласная переднего ряда между мягкими согласными» имеет, как правило, консервирующий, а не девиантный статус.

Итак, следует констатировать, что развитие полногласия в восточнославянских языках по модели *telt > telet / telot является столь же закономерным и даже обычным, как и постулируемый до сих пор в литературе, особенно учебной ${ }^{26}$, переход *telt > tolot.

23 Допустимость такого рода аналогии была предложена ещё ранее, см. (Torbiörnsson 1901, 48). Впоследствии о контаминации (= аналогии) в вокальной системе дифтонгических сочетаний с плавными подробно рассуждал украинский языковед В.А. Розов в докладе на I (Пражском, 1929 г.) съезде славистов (Розов 1932). Впрочем, как справедливо отмечал Ф.П. Филин $(1962,239)$, «аналогия сама по себе ещё не является доказательством».

${ }^{24}$ На это впервые совершенно определённо указала Л.В. Куркина (1973): «на ограниченной территории в качестве названия шелухи, мякины представлена синонимичная основа *pel-, состоящая из корня в сочетании с различными суффиксами», в частности, $-n$ и $-v$.

${ }^{25}$ Именно так можно трактовать процесс на упомянутой выше карте № 62 *pelva в (ОЛА 2019), где сочетания elo и el’o подаются одним знаком. Однако «читабельность» карты, на которой с использованием 42 отдельных знаков представлен весь славянский материал, при таком подходе всётаки выше, чем ещё большее их дробление по не главному для этой карты основанию - качеству плавного.

${ }^{26}$ См. (Илиади 2014, 117) со ссылками на известные учебники по исторической грамматике (истории) русского языка Л.П. Якубинского, П.Я. Черных, В.В. Иванова. Любопытно, однако, что 
В общем виде конечное преобразование *telt $>$ tolot историческая фонетика праславянского языка трактует следующим образом. Дифтонгическое сочетание telt, в котором последний согласный был твёрдым, в результате регрессивной ассимиляции к последующему твёрдому согласному перешло в tett с твёрдым $t^{27}$. Далее $t$ воздействовал на предшествующий гласный $e$, который также получил лабиализацию и сдвинулся в задний ряд. В результате этой лабиовеляризации первоначальное tett изменилось в tott; при этом возникающий после $t$ глайд ассимилятивно получил $o$ - окраску с дальнейшим его развитием в гласный полного образования: *telt $>*$ telt $>*$ tått $>*$ tåto $^{0} t>$ tolot; см. (ОЛА 2019, 9).

Таким образом, ключевыми параметрами трансформации *telt $>$ tolot являются a) регрессивная ассимиляция и вызванная ею б) лабиовеляризация $l>t$. Однако переход *telt $>$ telet в эту схему никак не вписывается (исключая, разумеется, упомянутую выше модель типа ${ }^{*} s^{(\prime)} e l z^{(')} e n a \rightarrow *$ selezena).

На второй момент, т. е. лабиовеляризацию плавного, обратил внимание А.И. Илиади. По его мнению,

причина $[\ldots]$ «незакономерного» развития в восточнославянском слов с формулой telt, видимо, заключается в существовании древних ареальных вариантов произношения этой последовательности звуков. Это значит, что в некоторых позднепраславянских диалектах, что стали основой будущих древнерусских говоров, не было, как в других, лабиовеляризации плавного $l$, потому telt здесь изменилось в telet, a не tolot или telot ${ }^{28}$ (Илиади 2014, 117).

Вместе с тем, есть основания вновь оценить и первую позицию, связанную с изменением telt, а именно процесс регрессивной ассимиляции плавного к последующему твёрдому согласному. Необходимо считаться с тем, что в отдельных случаях направление влияния в сочетании *telt было, как показывает приведённый выше материал, прогресси вным (впрочем, возможно, и не всегда вполне последовательно): мягкий начальный консонант способствовал сохранению $e$ с последующим влиянием на качество $l$, в результате чего возникающий после $l$ глайд также был переднерядным, нелабиальным. Развитие *telt получило следующую последовательность, которую следует охарактеризовать как закономерную: *tełt $>$ *tełt $>$ *teto $t>$ telet $^{29}$; подробнее см. (ОЛА 2019, 9).

в некоторых новых учебниках, например, (Колесов 2008, 56-61) вопрос о полногласной трансформации *telt просто опускается.

27 Н.Н. Дурново в вышедшем в 1924 г. «Очерке истории русского языка» видел это несколько иначе - без процесса ассимиляции, ср.: «Очевидно, согласная л в этих сочетаниях уже тогда [т. е. в позднепраславянскую эпоху. - Н.А.] звучала очень твердо. Следовательно, изменение $e, b$ в $o, b$ в таких сочетаниях указывает на более раннее общерусское изменение $л$ среднего в $л$ велярно-зубное перед согласными, независимо от качества следующего согласного звука, т. е. не только перед твердыми, но и перед мягкими» (Дурново 2000, 144).

28 Полагаю, что здесь имеются в виду сочетания с начальными шипящими $\check{z},, ~ \check{s}$ и и аффрикатой $\check{c}$ '.

29 Идея высказана П.Е. Гриценко во время обсуждения редакционной коллегией соответствующей части «Введения» в (ОЛА 2019). Однако на принципиальную возможность смягчения плавного «по 
Возможные механизмы фонетического процесса *telt > telet / telot можно представить в следующем виде (на примере *pelva):

1. Прогрессивная ассимиляция (невеляризованный $l$ ):

*pelva $\rightarrow p$ »el'eva $\rightarrow$ peleva.

2. Прогрессивная ассимиляция (веляризованный $t$ ):

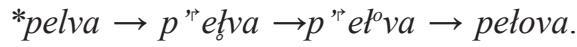

Во втором случае прогрессивная ассимиляция способствует консервации $e$ в первом слоге полногласного сочетания.

Оценивая картину распространения в восточнославянских диалектах полногласных сочетаний с -еле- / -ело-, следует в целом поддержать мнение А.И. Илиади о преимущественно периферийном (и таким образом, сугубо консервирующем) характере «древнего диалектного варьирования telt : telet / telot» (Илиади 2014, 117), но только по отношению к русским диалектным континуантам с явным тяготением к севернорусским говорам. Ареальная же картина украинских и белорусских соответствий такой периферийности в пределах восточной Славии всё-таки не подтверждает, что может быть следствием действия факторов иного рода, дескрипция и анализ которых может быть предметом отдельного исследования.

\section{Сокращения}

арх. - архангельский; бел. - белорусский; берез. - березинский; в.-двин. - верхнедвинский; волог. - вологодский; ворон. - воронежский; вост.-полес. - восточнополесский; вост.-слав. восточнославянский; вят. - вятский; дауг. - даугавпилсский; диал. - диалектный; др.-рус. древнерусский; лат. - латышский; лит. - литовский; лудз. - лудзенский; новг. - новгородский; подмоск. - подмосковный; прасл., праслав. - праславянский; рус. - русский; рос. - россонский; сев.-рус. - севернорусский; сен. - сенненский; сербохорв. - сербскохорватский; ст.-бел. старобелорусский; ст.-польск. - старопольский; ст.-рус. - старорусский; ст.-укр. - староукраинский; терск. - терский; толоч. - толочинский; укр. - украинский; центр.-полес. - центральнополесский; черниг. - черниговский; черногор. - черногорский; юж. - южный; яросл. - ярославский.

\section{Литература}

Аникин A.E. [Anikin A.E.] (2005), Опыт словаря лексических балтизмов в русском языке [Opyt slovarya leksicheskih baltizmov v russkom yazyke], Новосибирск.

Аникин A.E. [Anikin A.E.] (2007-), Русский этимологический словарь [Russkij étimologicheskij slovarj], вып. I-, Москва.

БЕР, Български етимологичен речник [Bŭlgarski etimologichen rechnik], т. I-, София, 1962-.

Бурнашев В.П. [Burnashev V.P.] (1843-1844), Опыт терминологического словаря сельского хозяйства, фабричности, промыслов и быта народного [Opyt terminologicheskogo slovarya selskogo chozyajstva, fabrichnosti, promyslov i byta narodnogo], т. I-II, C.-Петербург.

принципу прогрессивной ассимиляции» (в отношение tert, которое реализовалось в *bergъ > *ber'gъ > берегъ) уже указывалось, см. (Филин 1962, 253). 
Горяев Н.В. [Goryaev N.V.] (1896), Сравнительный этимологический словарь русского язы$к а$ [Sravnitelnyj etimologicheskij slovarj russkogo yazyka], Тифлис.

ГСБМ, Гістарычны слоўнік беларускай мовы [Histarychny sloŭnik belaruskaj movy], вып. I-XXXVII, Мінск, 1982-2017.

Даль В.И. [Dal V.I.] (1903-1909), Толковый словарь живого великорусского языка [Tolkovyj slovarj zhivogo velikorusskogo yazyka], т. I-IV, 3-е изд., С.-Петербург - Москва.

Дурново H.H. [Durnovo N.N.] (2000), Очерк истории русского языка [Ocherk istorii russkogo yazyka], [в:] Избранные работы по истории русского языка, Москва.

ЕСУМ, Етимологічний словник української мови [Etymologichnij slovnyk ukrayinskoyi movy], т. I-VI, Київ 1982-2012.

Илиади А.И. [Iliadi A.I.] (2014), Этимологический комментарий к нескольким славянским изоглоссам в труде А.А. Шахматова «К истории звуков русского языка» [Étimologicheskij kommentarij $k$ neskolkim slavyanskim izoglossam v trude A.A. Shahmatova «K istorii zvukov russkogo yazyka»], [в:] Типологія мовних значень у діахронічному та зіставному аспек$\max$ : зб. наук. праць, вип. XXIX, Вінниця, с. 111-120.

Клосс Б.М. [Kloss В.М.] (1987), Летопись Новгородская первая [Letopisj Novgorodskaya pervaya], [в:] Словарь книжников и книжности Древней Руси, вып. I: XI - первая половина XIV в., Ленинград, с. 245-247.

Колесов В.В. [Kolesov V.V.] (2008), Историческая грамматика русского языка [Istoricheskaya grammatika russkogo yazyka], С.-Петербург.

Куркина Л.В. [Kurkina L.V.] (1973), Славянские этимологии: <...> *pel- / *pelv- [Slavyanskie etimologii: <..> *pel- / *pelv-], „Этимология”, 1971, с. 91-92.

Куркина Л.В. [Kurkina L.V.] (2018), К реконструкиии этимологического гнезда с основой *telp- [K rekonstrukcii étimologicheskogo gnezda s osnovoj *telp-], [в:] Tруды Института русского языка им. В.В. Виноградова, вып. ХVIII: Этимология, Москва, с. 131-142.

ЛАБНГ, Лексічны атлас беларускіх народных гаворак [Leksichny atlas belaruskih narodnyh gavorak], т. I-V, Мінск 1993-1998.

Лавровский П.А. [Lavrovskij Р.A.] (1858), О русском полногласии [O russkom polnoglasii], [в:] Известия Императорской Академии Наук по Отделению русского языка и словесности, т. VII, вып. 5, С.-Петербург, с. 193-240.

Максимович М.A. [Maksimovich М.A.] (1839), История древней русской словесности [Istoriya drevnej russkoj slovesnosti], кн. I, Киев, с. 133-140.

Максимович М.A. [Maksimovich М.A.] (1848), Начатки русской филологии [Nachatki russkoj filologii], кн. І, Киев.

Никончук M.B. [Nykonchuk M.V.] (1979), Матеріали до лексичного атласу украӥнської мови (Правобережне Полісся) [Materialy do leksychnogo atlasu ukrayinskoyi movy (Pravoberezhne Polissya)], Київ.

НПЛ, Новгородская первая летопись старшего и младшего изводов [Novgorodskaya pervaya letopisj starshego i mladshego izvodov], Москва - Ленинград, 1950.

НОС, Новгородский областной словарь [Novgorodskij oblastnoj slovarj], С.-Петербург, 2010.

Потебня А.А. [Potebnya A.A.] (1876), К истории звуков русского языка [K istorii zvukov russkogo yazyka], Воронеж.

ОЛА (2019), Slovanský jazykový atlas. Foneticko-gramatická série, svazek 9, Reflexy *tort, *tolt, *tert, *telt, *ort, *olt, Praha. 
Преображенский А.Г. [Preobrazhenskij A.G.] (1910-1914), Этимологический словарь русского языка [Étimologicheskij slovarj russkogo yazyka], т. I-II, Москва.

ПОС, Псковский областной словарь с историческими данными [Pskovskij oblastnoj slovar $s$ istoricheskimi dannymi], вып. I-, Ленинград - С.-Петербург, 1967-.

Розов В. [Rozov V.] (1932), Eще о формулах tort, tolt, tert, telt [Eshche o formulah tort, tolt, tert, telt], Sborník praci I. sjezdu slovanských filologi̊ v Praze 1929, sv. II: Přednáški, Praha, s. $668-695$.

PCA, Речник српскохрватског књижевног и народног језика [Rechnik srpskohrvatskog knjizhevnog i narodnog jezika], књ. I-, Београд, 1959-.

СВГ, Словарь вологодских говоров [Slovarj vologodskih govorov], вып. I-XII, Вологда 19832007.

Скляренко В.Г. [Skljarenko V.G.] (2007), Повноголосся [Povnogolossya], [в:] Украӥнська мова. Енциклопедія, вид. 3, Київ, с. 516.

Сл. ПЗБ, Слоўнік беларускіх гаворак паўночна-заходняй Беларусі $і$ яе пагранічча [Sloŭnik belaruskih gavorak paŭnochna-zahodnyaj Belarusi i yae pagranichcha], т. I-V, Мінск 1979-1982.

СлРЯ XI-XVII, Словарь русского языка XI-XVII вв. [Slovarj russkogo yazyka XI-XVII vv.], т. I-, Москва 1975-.

СРГК, Словарь русских говоров Карелии и сопредельных областей [Slovarj russkih govorov Karelii i sopredelnyh oblastej], вып. I-VI, С.-Петербург 1994-2005.

СРГРС, Словарь говоров Русского Севера [Slovarj govorov Russkogo Severa], т. I-, Екатеринбург 2001-.

Срезневский И.И. [Sreznevskij I.I.] (1893-1912), Материальь для словаря древнерусского языка по письменнымм памятникам [Materialy dlya slovarya drevnerusskogo yazyka po pismennym pamyatnikam], т. I-III, C.-Петербург.

СРНГ, Словарь русских народных говоров [Slovar russkih narodnyx govorov], вып. I-, Ленинград - Москва - С.-Петербург, 1965-.

СУМ XVI-XVII, Словник украӥнської мови XVI - першої половини XVII cm. [Slovnуk ukrayinskoyi movy XVI - pershoyi polovyny XVII st.], вип. 1-, Львів, 1994-.

Фасмер М. [Fasmer М.] (1964-1973), Этимологический словарь русского языка [Étimologicheskij slovarj russkogo yazyka], т. I-IV, Москва.

Филин Ф.П. [Filin F.P.] (1962), Образование языка восточных славян [Obrazovanie yazyka vostochnyh slavyan], Москва.

Шахматов А.A. [Shahmatov A.A.] (1902), K истории звуков русского языка. II. Первое u второе полногласие [K istorii zvukov russkogo yazyka. II. Pervoe i vtoroe polnoglasie], „Известия Императорской Академии наук по Отделению русского языка и словесности”, т. VII, кн. 2, с. 303-382.

Шахматов А.А. [Shahmatov A.A.] (1903), К истории звуков русского языка. О полногласии и некоторых других явлениях [K istorii zvukov russkogo yazyka. O polnoglasii $i$ nekotoryh drugih yavleniyah], С.-Петербург.

Шахматов А.A. [Shahmatov A.A.] (1915), Очерк древнейшего периода истории русского языка [Ocherk drevnejshego perioda istorii russkogo yazyka], Петроград.

Шевельов Ю. [Shevelov Yu.] (2002), Історична фонологія української мови [Istorichna fonologiya ukrayinskoyi movi], Харків. 
Шерцль В.И. [Shercl V.I.] (1871), Сравнительная грамматика славянских и других родственных языков [Sravnitelnaya grammatika slavyanskih $i$ drugih rodstvennyh yazykov], ч. 1: Фонетика, Харьков.

ЭСБМ, Этымалагічны слойнік беларускай мовы [Étymalagichny sloŭnik belaruskaj movy], т. I-, Мінск 1978-.

ЭССЯ, Этимологический словарь славянских языков. Праславянский лексический фонд [Étimologicheskij slovarj slavyanskih yazykov. Praslavyanskij leksicheskij fond], вып. I-, Москва 1974-.

Derksen R. (2008), Etymological Dictionary of the Slavic Inherited Lexicon, Leiden - Boston.

ESJSt, Etymologický slovník jazyka staroslověnského, sv. 1-19, Praha 1989-2018.

Machek V. (1957), Etymologický slovnik jazyka českého a slovenského, Praha.

Peciar Š. (1952), Kritický prehl'ad prác o tzv. metatéze likvíd, [6:] Jazykovedný sborník Slovenskej akadémiy vied a umení, VI, Bratislava.+56+SP, Stownik prasłowiański, t. I-, Wrocław 1974-.

Torbiörnsson T. (1901), Die gemeinslavische Liquidametathese, I, Uppsala. 